\title{
Prevalence of potential mediators of artemisinin resistance in African isolates of Plasmodium falciparum
}

\author{
Afolabi Owoloye ${ }^{1,2}$, Michael Olufemi ${ }^{1,2}$, Emmanuel T. Idow ${ }^{2}$ and Kolapo M. Oyebola ${ }^{1,2,3^{*}}$ (1)
}

\begin{abstract}
Background: The devastating public health impact of malaria has prompted the need for effective interventions. Malaria control gained traction after the introduction of artemisinin-based combination therapy (ACT). However, the emergence of artemisinin (ART) partial resistance in Southeast Asia and emerging reports of delayed parasite sensitivity to ACT in African parasites signal a gradual trend towards treatment failure. Monitoring the prevalence of mutations associated with artemisinin resistance in African populations is necessary to stop resistance in its tracks. Mutations in Plasmodium falciparum genes pfk13, pfcoronin and pfatpase6 have been linked with ART partial resistance.

Methods: Findings from published research articles on the prevalence of pfk13, pfcoronin and pfatpase6 polymorphisms in Africa were collated. PubMed, Embase and Google Scholar were searched for relevant articles reporting polymorphisms in these genes across Africa from 2014 to August 2021, for pfk13 and pfcoronin. For pfatpase6, relevant articles between 2003 and August 2021 were retrieved.
\end{abstract}

Results: Eighty-seven studies passed the inclusion criteria for this analysis and reported 742 single nucleotide polymorphisms in 37,864 P. falciparum isolates from 29 African countries. Five validated-pfk 13 partial resistance markers were identified in Africa: R561 H in Rwanda and Tanzania, M476I in Tanzania, F446I in Mali, C580Y in Ghana, and P553L in an Angolan isolate. In Tanzania, three (L263E, E431K, S769N) of the four mutations (L263E, E431K, A623E, S769N) in pfatpase6 gene associated with high in vitro $\mathrm{I}_{50}$ were reported. pfcoronin polymorphisms were reported in Senegal, Gabon, Ghana, Kenya, and Congo, with P76S being the most prevalent mutation.

Conclusions: This meta-analysis provides an overview of the prevalence and widespread distribution of pfk 13, pfcoronin and pfatpase6 mutations in Africa. Understanding the phenotypic consequences of these mutations can provide information on the efficacy status of artemisinin-based treatment of malaria across the continent.

Keywords: Artemisinin-based combination therapy, Partial resistance, Plasmodium falciparum, Kelch-13, Pfcoronin, pfatpase6, Mutations, Africa

\footnotetext{
*Correspondence: oyebolakolapo@yahoo.com

${ }^{1}$ Genomic Research in Biomedicine Laboratory, Biochemistry

and Nutrition Department, Nigerian Institute of Medical Research, Lagos, Nigeria

Full list of author information is available at the end of the article
} original author(s) and the source, provide a link to the Creative Commons licence, and indicate if changes were made. The images or other third party material in this article are included in the article's Creative Commons licence, unless indicated otherwise in a credit line to the material. If material is not included in the article's Creative Commons licence and your intended use is not permitted by statutory regulation or exceeds the permitted use, you will need to obtain permission directly from the copyright holder. To view a copy of this licence, visit http://creativecommons.org/licenses/by/4.0/. The Creative Commons Public Domain Dedication waiver (http://creativeco mmons.org/publicdomain/zero/1.0/) applies to the data made available in this article, unless otherwise stated in a credit line to the data. 


\section{Graphical Abstract}

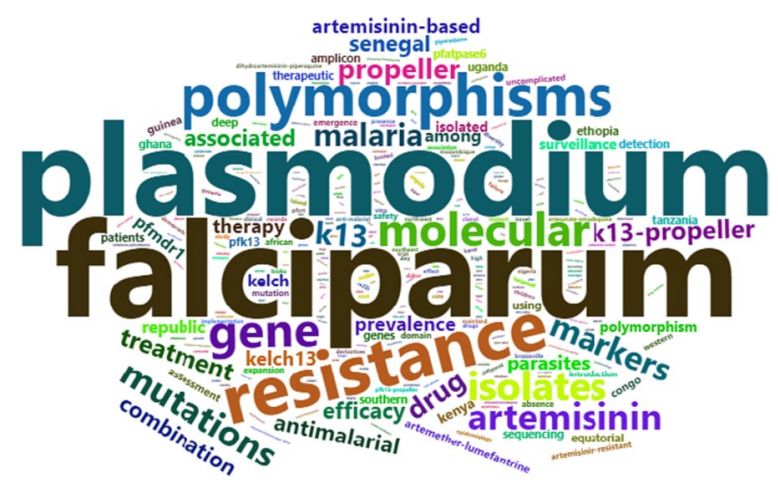

\section{Background}

Malaria is a leading cause of mortality and morbidity especially among children under five years old in Africa [1]. Interventions such as insecticide-treated nets, space spraying, indoor residual spraying, larval control, and anti-malarial therapeutics have been adopted to reduce malaria burden across the continent [2]. However, these strategies can be limited by the emergence of resistant strains of both mosquitoes and parasites [3-5].

A major setback to malaria control is the emergence and spread of partial resistance to artemisinin, defined as slow parasite clearance expressed in early ring-stage parasites and polymorphisms in the parasite Kelch-13 propeller gene [6-10]. Plasmodium falciparum Kelch13 (pfk13) encodes a protein with 726 amino acids. The polypeptide consists of a poorly conserved $\mathrm{N}$-terminal region (Apicomplexa-specific; amino acid from 1 to 211) and three highly conserved regions [10]. It has a coiledcoil-containing ((CCC); amino acid from 212 to 341), broad-complex, tram track, and bric-a-brac ((BTB); amino acid from 350 to 437) and a C-terminal kelchrepeat propeller ((KREP); amino acid from 443 to 726), which harbours virtually all $p f k 13$ allelic variants associated with artemisinin resistance [11]. Kelch-13 gene is putatively associated with intra-erythrocytic growth and proliferation of $P$. falciparum asexual parasites [12, 13]. Validated $p f k 13$ gene mutations that have been associated with partial artemisinin resistance include C580Y, R561H, F446I, P574L, N458Y, I543T M476I, R539T, $\mathrm{Y} 493 \mathrm{H}$, and P553L $[1,10,14]$.

In addition, polymorphisms in P. falciparum coronin (pfcoronin) gene have been linked with possible artemisinin resistance $[15,16]$. The pfcoronin protein belongs to the actin-binding protein family, which has been associated with the motility of sporozoites [17]. Pfcoronin encodes a protein with 602 amino acids. The propeller domain of pfcoronin has seven blades. This domain is made up of the WD40 repeats (tryptophan-aspartic acid 40) and a $\beta$-propeller in the $\mathrm{N}$-terminus region [18]. Pfcoronin is involved in organization of F-actin via its $\mathrm{N}$-terminal propeller region and localizes to the parasite membrane [17]. Demas et al. [16] demonstrated in long-term cultivation of Senegalese isolates that G50E, R100K and E107V polymorphisms in pfcoronin reduced the susceptibility of the parasites to dihydroartemisinin, the active component of artemisinin. However, these three pfcoronin mutations were not detected in field isolates obtained from various endemic countries in Africa, instead a new mutation P76S has been identified [19-21]. This P76S mutation, however, has not shown any predictive effect on reduced efficacy to artemisinin derivatives $[19,20]$. As the pfcoronin gene is structurally similar to the six-bladed PfKelch13 propeller domain [18], the extent of interaction between pfcoronin and Pfkelch13 mutations requires further examination [15].

Previous studies investigated the association pfatpase6 mutations and artemisinin resistance [22, 23]. The theory of association was based on the mechanism of action of artemisinin on pfatpase6, which aggravates calcium homeostasis of P. falciparum [24, 25]. Sarco-endoplasmic reticulum $\mathrm{Ca}^{2+}$ ATPase (SERCA), the calcium pump of sarcoplasmic reticulum responsible for refilling calcium in the endoplasmic reticulum (ER) stores, is critically important for cellular homeostasis and calcium transport and signalling functions [26, 27]. Dissimilar from vertebrates possessing three SERCA genes [28], P. falciparum has a single SERCA gene, otherwise known as pfatpase6 [29]. While some pfatpase6 polymorphisms have been reported in field isolates [30], the consensus is that pfatpase6 is not directly involved in artemisinin action or resistance [12, 31]. Be that as it may, the current reliance on artemisinin derivatives for falciparum malaria treatment has stressed the importance of a synergistic effort to monitor the emergence and spread of mutations linked 
with artemisinin resistance in Africa. This meta-analysis collated the prevalence of $p f k 13$, pfcoronin and pfatpase 6 polymorphisms across different endemic settings in Africa.

\section{Methods}

This article followed the guidelines for systematic reviews and meta-analyses [32]. Published research documents and collated data on the prevalence of $p f k 13$, pfcoronin and pfatpase 6 mutations across endemic countries in Africa were used in this report. Two electronic biomedical databases (PubMed and Embase) were methodically explored for peer-reviewed $p f k 13$ and pfcoronin articles published between 2014 and 2021, and for pfatpase6, peer-reviewed articles published between 2003 and 2021, which had the relevant study populations (i.e., clinical or community surveys), study design and expected outcomes for this review. Google Scholar was also combed for relevant peer-reviewed articles. Both interventional and observational studies were retrieved and included in the review using the "MeSH" search terms "OR" and "AND": "kelch13" OR "kelch-13" OR "pfk13" OR "Pfkelch13" OR "Pfkelch-13" OR "Plasmodium falciparum drug resistance" OR "ATP6" OR "'Plasmodium falciparum ATP6" OR "Plasmodium falciparum ATPase6" OR "PfATP6" "pfatpase6" OR "Plasmodium falciparum coronin" OR "pfcoronin" OR "Plasmodium falciparum coronin" OR "molecular marker" OR "Plasmodium falciparum" "P. falciparum" OR "falciparum malaria" AND ("African" OR "Africa" OR with each name of the 54 countries in Africa). The citations of the individual search were saved and sent to the reference manager (EndNote version 9.0). The full texts of retrieved citations were downloaded using EndNote. Articles with data from unknown countries and/or sampling sites as well as systematic reviews, conference presentations, letters or correspondence to editors and abstracts with insufficient information were removed.

\section{Inclusion criteria}

The articles included in this review strictly reported $P$. falciparum artemisinin resistance markers, single nucleotide polymorphisms (SNPs) in African countries, polymorphisms in pfk13, pfcoronin and/or pfatpase6 confirmed through targeted or whole-genome sequencing. Articles written in English language, from cross-sectional studies such as clinical or community surveys were included, in addition to longitudinal studies of treatment efficacy. Specific studies reporting synonymous and nonsynonymous SNPs in pfk13, pfatpase6 and pfcoronin were eligible for this meta-analysis.

\section{Exclusion criteria}

Articles reporting molecular markers other than $p f k 13$, pfatpase6, and pfcoronin were excluded from this review. In addition, studies with no definite $p f k 13$, pfatpase6, and pfcoronin SNPs reported either in the main manuscript or Additional file 1 were excluded. Studies reporting pfk13, pfatpase6, and pfcoronin polymorphisms without sequencing techniques were not included.

\section{Definitions}

Partial resistance to artemisinin refers to delayed or slow clearance of ring-stage malaria parasites from the bloodstream following treatment with an artemisininbased combination therapy [27]. Delayed parasite clearance does not necessarily cause treatment failure. This review utilized the World Health Organisation list of P. falciparum artemisinin resistance SNPs classifying pfk 13 mutations into validated and candidate SNPs [33]. Pfk13-validated SNPs are significantly associated with reduced drug susceptibility in laboratory assays and a slow parasite clearance rate in field studies [33]. Validated-pfk13 SNPs include C580Y, R561H, F446I, P574L, N458Y, I543T M476I, R539T, P553L, and Y493H [14]. On the other hand, candidate SNPs are mutations associated with slow parasite clearance in clinical trials but not confirmed in vitro [33]. These include P441L, G449A, C469F/Y, A481V/C, R515K, P527H, N537I/D, G538V, V568G, R622I, and A675V [14]. Other rare variants reported to be associated with delayed clearance but at low frequencies include D452E, C469Y/W, K479I, R515K, S522C, N537D, R575K, M579I, D584V, P667T, and $\mathrm{H} 719 \mathrm{~N}$ [14].

\section{Data extraction}

The extracted data from each article captured first and last author affiliations, the year the studies were conducted (Fig. 1), year of article publication (Fig. 2), geographic location of the study area, duration of the study, age of the participants and the type of study design (that is, interventional $v s$ observational). Data involving sampling strategies, molecular assays performed, clinical status of the study population, and publication affiliation were also reported (Fig. 3).

\section{Results}

PubMed, Embase and Google Scholar databases were combed for relevant articles. The search yielded a total of 509 articles on pfk13, pfcoronin and pfatpase6 SNPs, of which 434 articles met inclusion criteria (Fig. 4). Eleven articles with unobtainable full texts were removed. Following an adjustment for duplication (i.e., research articles from the same authors which gave multiple search 


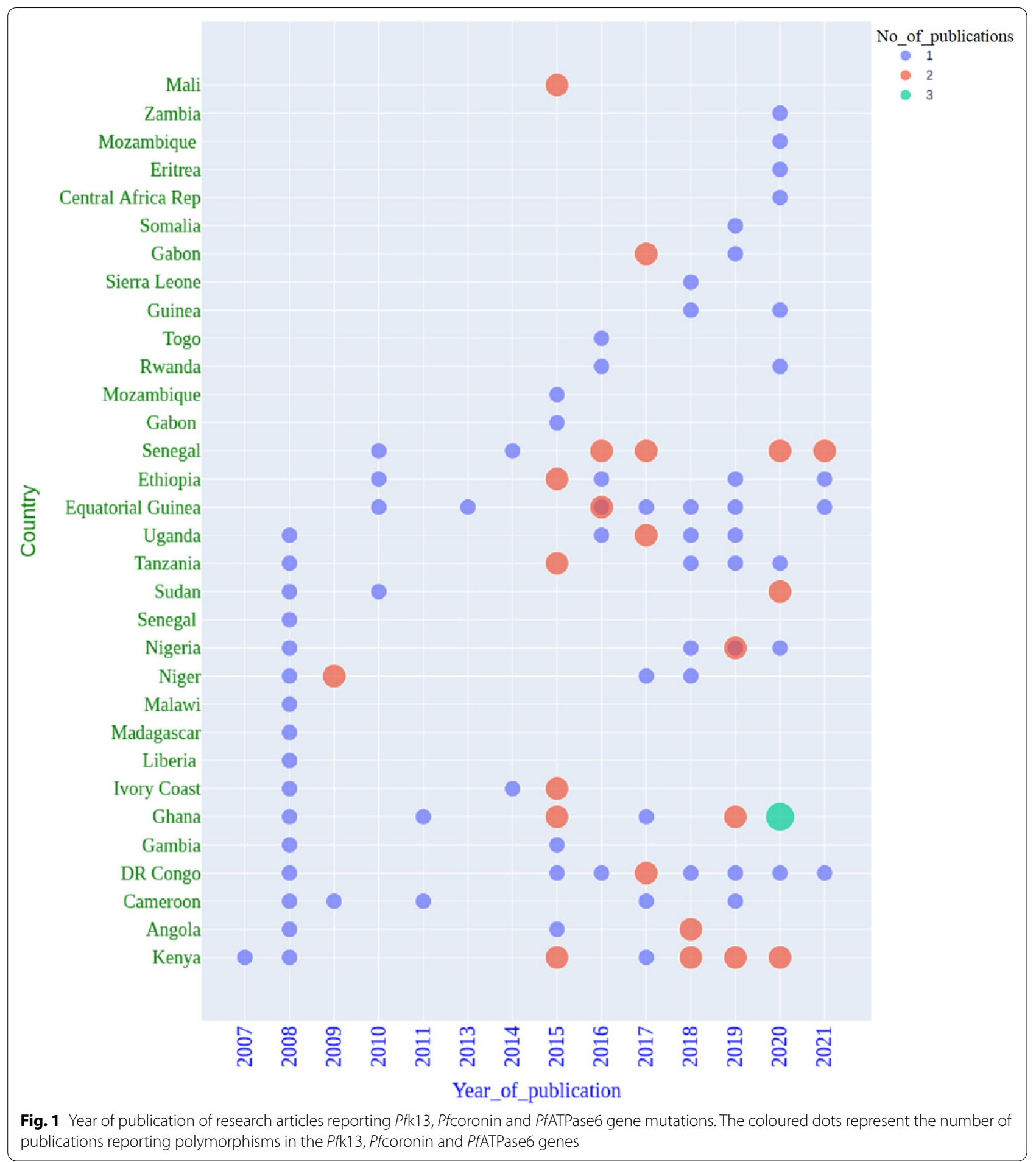

results or were probably pre-printed before publication), redundant articles were discarded. A total of 87 studies (66 on pfk13, three on pfcoronin and 18 on pfatpase
6) analysed $37,864(33,383,1,498$ and 2,983) isolates for pfk13, pfcoronin and pfatpase 6 polymorphisms, respectively. The isolates were collected in 29 African countries. 


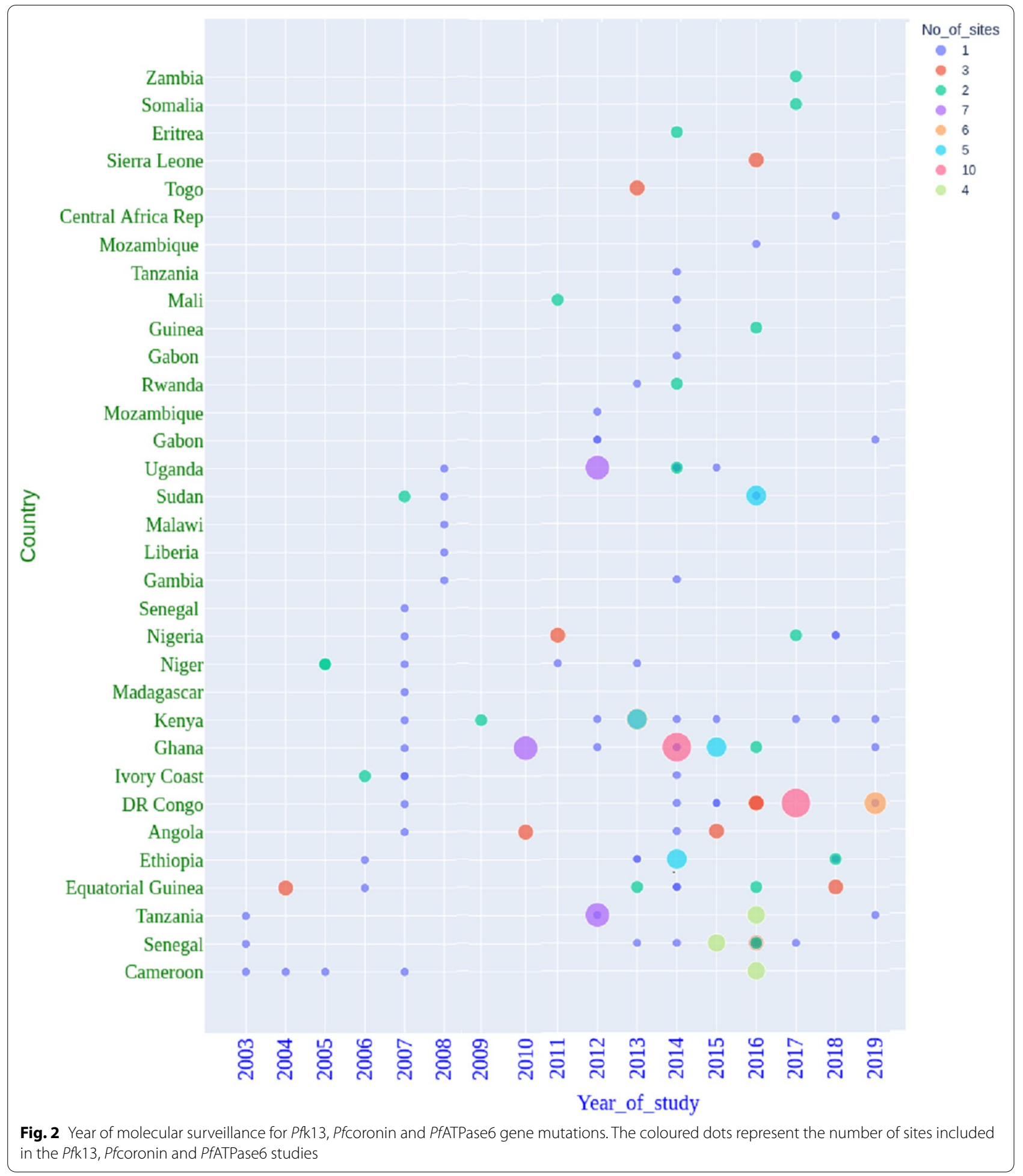

\section{Sample pre-processing and pfk 13 genotyping}

The majority of the studies collected blood samples for genotyping on filter paper [34-38] while others did not report the method used for collection [21, 39].
Plasmodium falciparum polymerase chain reaction positive $(\mathrm{PCR}+)$ samples were 18,292 out of 32,406 total samples collected [39-45], yielding PCR positivity rate of $56.4 \%$ malaria in both clinical and community 

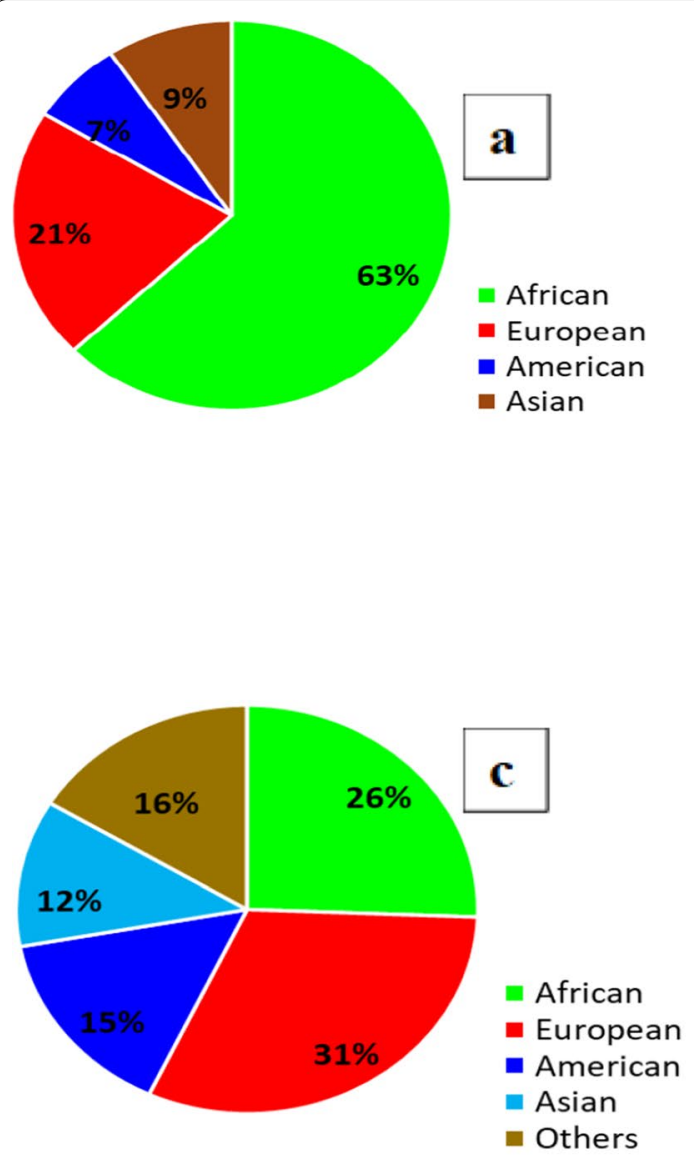

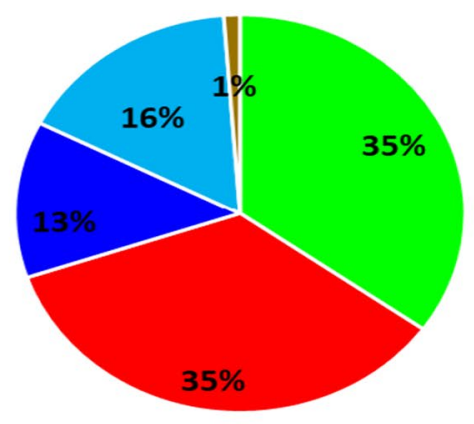

b

African

- European

- American

- Asian

- Others

\section{d}

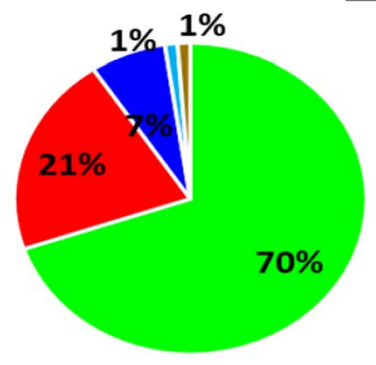

- Cross-sectional: clinic

- Cross-sectional: survey

- Sentinel site

- Travel study

- Unspecified
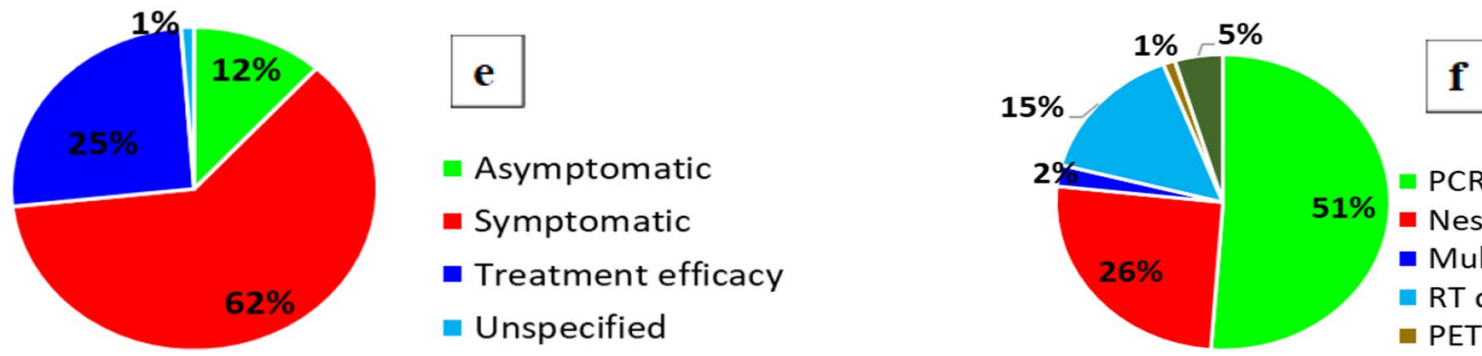

Fig. 3 Demography of research articles reporting Pfk13, Pfcoronin and PfATPase6 gene mutations. a First author affiliation, $\mathbf{b}$ Last author affiliation, $\mathbf{c}$ Where research funding came from $\mathbf{d}$ Sampling technique, $\mathbf{e}$ Clinical status, $\mathbf{f}$ Parasite detection and/or quantitation assays $(P C R=$ polymerase chain reaction; $\mathrm{RT}-\mathrm{qPCR}=$ real-time quantitative $\mathrm{PCR} ; \mathrm{PET}=$ photo-induced electron transfer)

studies. However, five studies did not report the number of PCR + samples [46-50]. pfk13 gene was successfully genotyped in 15,861 (86.71\%) samples using techniques such as targeted and whole-genome sequencing $[35,46-48]$. The variant-calling algorithms and data analysis software used included Mega software, Jalview,
Phylo, DnaSp, Genescan, Genome Assembly Program, PROVEAN and RStudio [51-54]. 


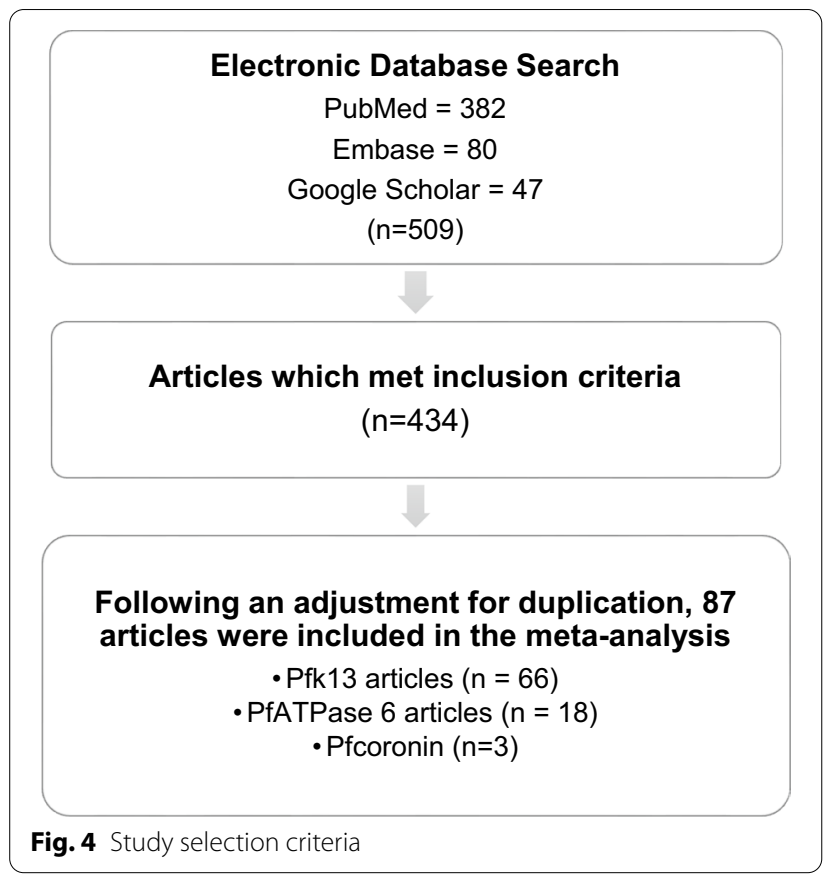

\section{Prevalence of pfk13 non-synonymous mutations across Africa}

At least one non-synonymous $p f k 13$ mutation was observed in 26 African countries (Fig. 5). The reported pfk13 non-synonymous SNPs occurring inside the propeller domain (amino acid from 443) include A578S/D/V (95 parasite isolates with the SNP); R561H (20 isolates with the SNP); R622G/K/I (20 isolates with SNP); N587K/I (16 isolates); V555A/L (9 isolates); S522C/M/N (9 isolates); T677A/K/R (9 isolates); Q613E/H (7 isolates), F509G (7 isolates) and V637I (6 isolates); N554H/K/D and A626S/T/V (5 isolates each); and, N609D/L/S (5 isolates) $[35,55-58]$. The most frequently reported mutations outside the propeller domain (amino acid below $443)$ include $\mathrm{K} 189 \mathrm{~T} / \mathrm{N}$ (105 isolates with the mutation) [51, 59], E208K (10 isolates) [60], N142NN (9 isolates) [61], T149S (6 isolates) [62], E433D (4 isolates) [54], and E401Q. Apart from D389H/N/Y (3 isolates), K378R (2 isolates) and D281V (2 isolates), other reported mutations outside the propeller domain (31/40) occurred singly $[54,59]$. K189T/N mutation had a high prevalence in Senegal $[51,61]$. Ten validated-pfk13 mutations (C580Y, R561H, F446I, P574L, N458Y, I543T M476I, R539T, Y493H, P553L) have been associated with artemisinin partial clearance [14] of which three $(\mathrm{R} 561 \mathrm{H}, \mathrm{P} 553 \mathrm{~L} / \mathrm{T}$, M476I) were identified in Africa [39, 55, 59]. R561H was identified in Rwanda and Tanzania [39, 63], P553T in Senegal [59], P553L in a patient returning from Angola

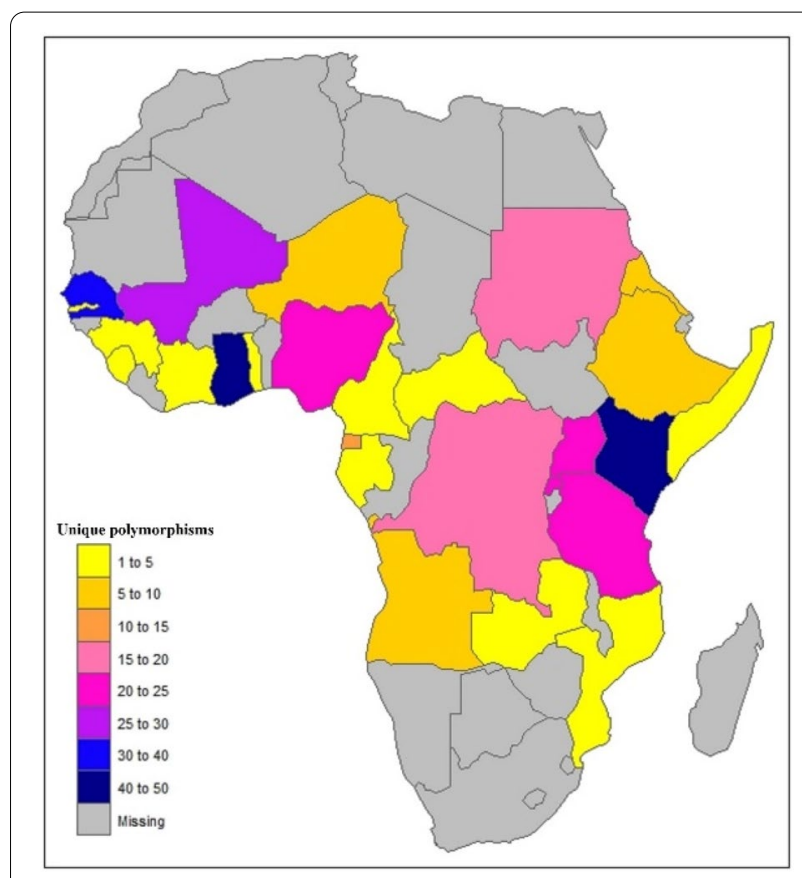

Fig. 5 Distribution of unique non-synonymous P. falciparum Kelch-13 single nucleotide polymorphisms (SNPs) in African countries [34-46, $48-56,59,60,62-64,66-68,73,74]$

to China [64], and M476I in Tanzania [55]. In two isolates from Ghana [40], asparagine in position 458 (N458) was found to be replaced by aspartic acid (D) instead of tyrosine $(\mathrm{Y})$.

\section{Prevalence of pfatpase 6 and pfcoronin non-synonymous mutations in Africa}

Six studies reported pfatpase6 polymorphisms [30, 6569]. The studies involved 1,323 samples of which $752 P$. falciparum isolates were PCR +, 644 (85.63\%) were successfully sequenced [65-68]. In Tanzania [30], three (L263E, E431K, S769N) of the four mutations (L263E, E431K, A623E, S769N) in pfatpase6 gene were reported. Pfatpase6 E431K was reported in Congo and Ethiopia.

Three studies reported pfcoronin mutations in $\mathrm{PCR}+$ field isolates. Pfcoronin gene was sequenced in 1,498 (100\%) isolates [19-21]. Pfcoronin mutations were reported in 21 countries: Ivory Coast, Guinea, Togo, Burkina, Benin, Mali, Nigeria, Senegal, Niger, Ghana, Sierra, Cameroon, Gabon, Democratic Republic of Congo, Central Africa, Chad, Mayotte, Eritrea, Tanzania, Sudan, and Kenya (Fig. 6); P76S polymorphism was identified in all 21 countries [19-21]. The frequency of P76S was higher in Senegal compared to the other countries (Fig. 6). V62M was reported in Ghana, Burkina Faso, Nigeria, 


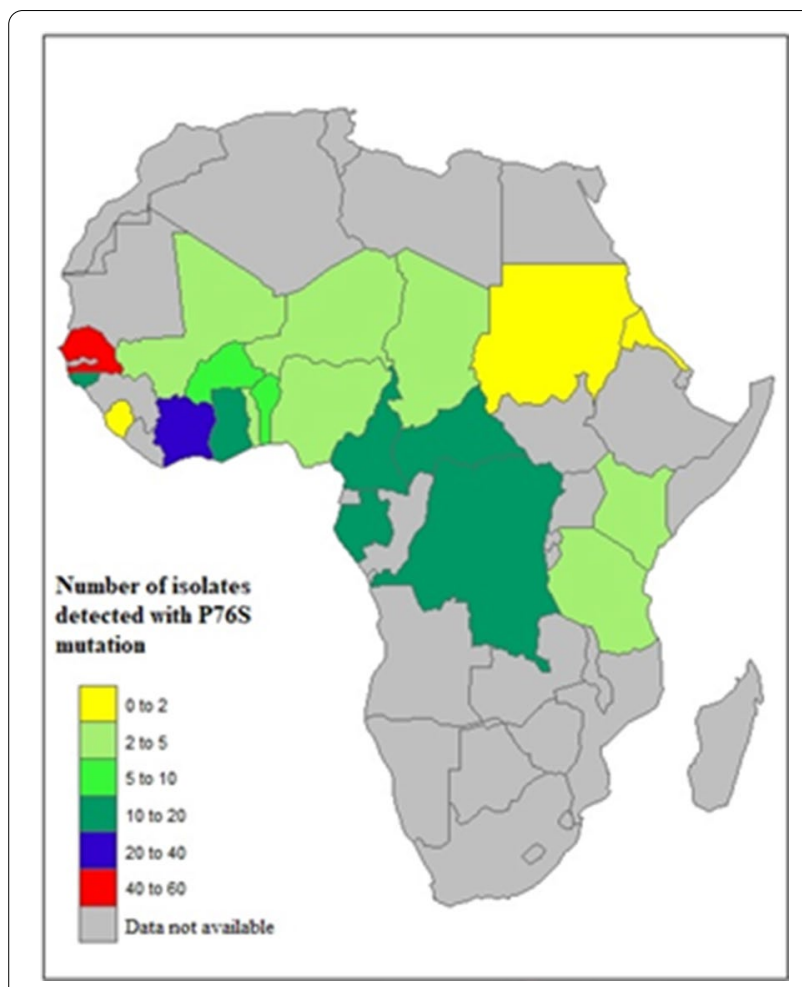

Fig. 6 Number of P. falciparum isolates with Pfcoronin P76S mutation in Africa $[16,19,21]$

Cameroon, Central Africa Republic, Chad, and Gabon (Table 1, Fig. 6). Pfcoronin polymorphism was associated with reduced susceptibility in $P$. falciparum adapted long-term to artemisinin [16].

\section{Discussion}

The emergence of partial resistance to artemisinin in Southeast Asia (SEA) is an imminent danger to successful malaria control and elimination. The broad spectrum of polymorphisms in genes implicated in artemisinin resistance reported so far in Africa raises concern about potential adaptation of $P$. falciparum to artemisinin. Although the efficacy of current therapy remains high on the continent, there are emerging indications of varying parasite clearance times [70,71].

Compared to SEA, low prevalence of $p f k 13$ polymorphisms was recorded across Africa. This could be associated with the later introduction of artemisinin in Africa (between 2000 and 2005) accompanied by a shorter period of artemisinin drug pressure, unlike in East Asia which experienced early adoption of artemisinin in the 1970s [72]. Reports from SEA identified 10 validatedpfk13 polymorphisms [14], some of which have been identified in African isolates. For instance, R561H was identified in Rwanda and Tanzania [39] and M476I was detected in Tanzania [55]. Although R539T was not found, R539I was reported in Senegal, and in Kenya R539K was observed [48, 59]. P553T (threonine replaced leucine) was reported in Senegal [59]. The presence of these validated mutations in Africa is a red flag as this could be a precursor to total artemisinin resistance and/ or increased selection pressure on partner drugs.

Seven of the 11 candidate $p f k 13$ mutations [14] have been found in Africa. For instance, V568G and A481C were identified in Kenya [48] and Ghana [40], respectively, while A675V was reported in Kenya, Rwanda and Uganda [50,73]. The other associated markers identified, including C469W (instead of C469Y) [39, 59, 74], G538S (instead of G538V) [58], G449S/C (instead of G449A) [75], were also found in SEA but their respective amino acid substitutions were different. This raises questions about African parasites with potential artemisinin selection background differing from SEA parasites.

The suspected association of pfatpase 6 and pfcoronin with increased $\mathrm{IC}_{50 \text { s }}$ points to the possibility of nonpfk13 mutations. Pfatpase6 variants was identified in high frequency in Tanzania [30], although no evidence of delayed parasite clearance in the presence of artemisinin has been established. Pfatpase6 E431K was reported in Congo, Ethiopia and Ghana [65-67]. The variant was also reported in vitro to be associated with delayed artesunate-treated parasite clearance in Senegal [22]. However, a later study in Iran suggested that the role of E431K variant in artemisinin resistance was suspect [69]. Pfatpase6 E431K mutation often co-occurs with other pfatpase6 gene polymorphisms, usually the S769N and L623E mutations [76].

Research on pfcoronin as a potential marker of artemisinin resistance in African parasites is relatively recent and still evolving. Pfcoronin mutations reported so far include I53I, V62M, K69K/I/R, P76S, N110Y/D, N112Y/D, K115E, L121F, K127E, K127I/R, N134Y/D, N137Y/D, and N137I/S [19-21]. In 21 countries where pfcoronin was genotyped, P76S variant was observed in all the populations at varying frequencies: $26.3 \%$ in Senegal, $16.6 \%$ in Ivory Coast, $9.3 \%$ in Cameroon, $7.8 \%$ in Gabon, $5.4 \%$ in Ghana, 5.4\% Democratic Republic of Congo; all other countries at less than $5 \%$. None of the variants suspected to be associated with delayed parasite clearance in the presence of artemisinin pressure (E107V, G50E, and R100K) in laboratory isolates was reported in natural African populations. Even though pfcoronin polymorphisms $[20,21]$ have not yet been validated in clinical isolates as markers of delayed parasite clearance, their structural similarity with Pfkelch13 suggests the possibility of a common mechanism of resistance emergence $[20,77]$. As much as this meta-analysis is not minutely exhaustive, detailed analysis of the phenotypic effects of 
Table 1 The prevalence of Pfcoronin single nucleotide polymorphisms in Africa

\begin{tabular}{|c|c|c|c|}
\hline Country & Mutation (no of isolates with mutation) & $\begin{array}{l}\text { Prevalence of P76S } \\
\text { (\%) }\end{array}$ & References \\
\hline Senegal & P76S (54) & 26.3 & {$[19,20]$} \\
\hline Ivory coast & P76S (34) & 16.6 & [19] \\
\hline Cameroon & P76S (19), V62M (2) & 9.3 & [19] \\
\hline Gabon & V62M (7), P76S (16) & 7.8 & {$[19,21]$} \\
\hline Ghana & I53I (6), V62M (6), K69I/R (3), P76S (1 1), N1 10Y (6) & 5.4 & {$[19,21]$} \\
\hline Democratic Republic of Congo & $\begin{array}{l}\text { K69l/R (11), P76S (11), N110Y/D (5), N112Y (10, K115E (1), L121F (6), } \\
\text { K127E (6), K127I/R (5), N134Y/D (4), N137I/Y/D (12), }\end{array}$ & 5.4 & {$[19,21]$} \\
\hline Guinea & P76S (11) & 4.9 & [19] \\
\hline Central Africa Republic & P76S (10), V62M (2) & 4.9 & [19] \\
\hline Burkina Faso & P76S (6), V62M (2) & 2.9 & [19] \\
\hline Benin Republic & P76S (6) & 2.9 & [19] \\
\hline Mali & P76S (4) & 2.0 & [19] \\
\hline Nigeria & P76S(4), V62M (1) & 2.0 & [19] \\
\hline Kenya & P76S (4) & 2.0 & {$[19,21]$} \\
\hline Togo & P76S (3) & 1.5 & [19] \\
\hline Niger & P76S (3) & 1.5 & [19] \\
\hline Chad & P76S (3), V62M (2) & 1.5 & [19] \\
\hline Mayotte & P76S (2) & 1.0 & [19] \\
\hline Tanzania & P76S (2) & 1.0 & [19] \\
\hline Sierra & P76S (6) & 0.5 & [19] \\
\hline Eritrea & P76S (6) & 0.5 & [19] \\
\hline Sudan & P76S (6) & 0.5 & [19] \\
\hline
\end{tabular}

reported mutations is recommended to monitor continued efficacy or otherwise of artemisinin-based treatment of malaria in Africa.

\section{Conclusions}

Although artemisinin-based treatment of malaria remains largely potent in Africa and there is no evidence that full resistance has emerged, increased burden of mutations in genes implicated in artemisinin resistance can eventually cause total artemisinin resistance and/ or increased selection pressure on partner drugs. This calls for continued therapeutic efficacy monitoring and genomic surveillance across Africa.

\section{Abbreviations}

KREP: Kelch-repeat propeller; PCR: Polymerase chain reaction; pfatpase6: Plasmodium falciparum ATPase6; pfcoronin: Plasmodium falciparum Coronin; pfk 13: Plasmodium falciparum Kelch-13; SEA: Southeast Asia; SERCA: Sarco-endoplasmic reticulum $\mathrm{Ca}_{2}{ }^{+}$ATPase; SNP: Single nucleotide polymorphisms.

\section{Supplementary Information}

The online version contains supplementary material available at https://doi. org/10.1186/s12936-021-03987-6.

Additional file 1. Study sites and sample description
Acknowledgements

We appreciate the authors whose papers were reviewed in this manuscript.

Authors' contributions

$\mathrm{AO}$ and $\mathrm{KMO}$ conducted the literature review and drafted the manuscript. $\mathrm{AO}$, $\mathrm{MO}, \mathrm{ETI}$, and $\mathrm{KMO}$ reviewed the manuscript. All authors read and approved the final manuscript.

\section{Funding}

KMO was supported by the European and Developing Countries Clinical Trials Partnership (EDCTP) Career Development Fellowship (TMA2019CDF-2782)

The views expressed in this publication are those of the authors and not necessarily those of the European Union.

\section{Availability of data and materials}

All data generated or analysed during this study are included in this published article (and its additional files).

\section{Declarations}

Ethics approval and consent to participate

Not applicable.

\section{Consent for publication}

Not applicable.

\section{Competing interests}

The authors declare no competing interests.

\section{Author details}

${ }^{1}$ Genomic Research in Biomedicine Laboratory, Biochemistry and Nutrition Department, Nigerian Institute of Medical Research, Lagos, Nigeria. 
${ }^{2}$ Parasitology and Bioinformatics Unit, Department of Zoology, Faculty of Science, University of Lagos, Lagos, Nigeria. ${ }^{3}$ Sickle Cell Branch, National Heart Lung and Blood Institute, US National Institutes of Health, Bethesda, MD, USA.

Received: 7 July 2021 Accepted: 16 November 2021 Published online: 02 December 2021

\section{References}

1. WHO. Report on antimalarial drug efficacy, resistance and response: 10 years of surveillance (2010-2019). Geneva: World Health Organization; 2020.

2. Bhatt S, Weiss DJ, Cameron E, Bisanzio D, Mappin B, Dalrymple U, et al. The effect of malaria control on Plasmodium falciparum in Africa between 2000 and 2015. Nature. 2015;526:207-11.

3. Okell LC, Drakeley CJ, Ghani AC, Bousema T, Sutherland CJ. Reduction of transmission from malaria patients by artemisinin combination therapies: a pooled analysis of six randomized trials. Malar J. 2008;7:125.

4. Akinola O, Egboro DE, Iyenmoana E, Abdulkadir BF, Yakub YO, Adeosun $A A$, et al. Prevalence of antimalarial drug resistant markers in kwara, north-central, Nigeria: a decade after replacement of chloroquine and antifolates as first-line regimen. Am J Trop Med and Hyg. 2019;101:78.

5. Baraka V, Mavoko HM, Nabasumba C, Francis F, Lutumba P, Alifrangis M, et al. Impact of treatment and re-treatment with artemether-lumefantrine and artesunate-amodiaquine on selection of Plasmodium falciparum multidrug resistance gene-1 polymorphisms in the Democratic Republic of Congo and Uganda. PLoS One. 2018;13:e0191922.

6. Noedl H, Se Y, Schaecher K, Smith BL, Socheat D, Fukuda MM, et al. Evidence of artemisinin-resistant malaria in western Cambodia. N Engl J Med. 2008:359:2619-20

7. Dondorp AM, Nosten F, Yi P, Das D, Phyo AP, Tarning J, et al. Artemisinin resistance in Plasmodium falciparum malaria. N Engl J Med. 2009;361:455-67.

8. Amaratunga C, Sreng S, Suon S, Phelps ES, Stepniewska K, Lim P, et al. Artemisinin-resistant Plasmodium falciparum in Pursat province, western Cambodia: a parasite clearance rate study. Lancet Infect Dis. 2012;12:851-8.

9. Takala-Harrison S, Jacob CG, Arze C, Cummings MP, Silva JC, Dondorp $\mathrm{AM}$, et al. Independent emergence of artemisinin resistance mutations among Plasmodium falciparum in Southeast Asia. J Infect Dis. 2015:211:670-9.

10. Ariey F, Witkowski B, Amaratunga C, Beghain J, Langlois AC, Khim N, et al. A molecular marker of artemisinin-resistant Plasmodium falciparum malaria. Nature. 2014;505:50-5.

11. Anderson TJ, Nair S, McDew-White M, Cheeseman IH, Nkhoma S, Bilgic F, et al. Population parameters underlying an ongoing soft sweep in Southeast Asian malaria parasites. Mol Biol Evol. 2017;34:131-44.

12. Zhang HW, Li SJ, Hu T, Yu YM, Yang CY, Zhou RM, et al. Prolonged parasite clearance in a Chinese splenectomized patient with falciparum malaria imported from Nigeria. Infect Dis Poverty. 2017;6:44.

13. Bushell E, Gomes AR, Sanderson T, Anar B, Girling G, Herd C, et al. Functional Profiling of a Plasmodium genome reveals an abundance of essential genes. Cell. 2017;170:260-72.

14. WHO. World malaria report. 20 years of global progress and challenges. Geneva: World Health Organization; 2020. p. 2020.

15. Sharma Al, Shin SH, Bopp S, Volkman SK, Hartl DL, Wirth DF. Genetic background and PfKelch13 affect artemisinin susceptibility of PfCoronin mutants in Plasmodium falciparum. PLoS Genetics. 2020;16:e1009266.

16. Demas AR, Sharma Al, Wong W, Early AM, Redmond S, Bopp S, et al. Mutations in Plasmodium falciparum actin-binding protein coronin confer reduced artemisinin susceptibility. Proc Natl Acad Sci USA. 2018;115:12799-804.

17. Olshina MA, Angrisano F, Marapana DS, Riglar DT, Bane K, Wong W, et al. Plasmodium falciparum coronin organizes arrays of parallel actin filaments potentially guiding directional motility in invasive malaria parasites. Malar J. 2015;14:280

18. Ashley EA, Dhorda M, Fairhurst RM, Amaratunga C, Lim P, Suon S, et al. Spread of artemisinin resistance in Plasmodium falciparum malaria. N Engl J Med. 2014:371:411-23.
19. Delandre O, Gendrot M, Fonta I, Mosnier J, Benoit N, Amalvict R, et al. Prevalence of mutations in the pfcoronin gene and association with ex vivo susceptibility to common quinoline drugs against Plasmodium falciparum. Pharmaceutics. 2021;13:1273.

20. Delandre O, Daffe SM, Gendrot M, Diallo MN, Madamet M, Kounta MB, et al. Absence of association between polymorphisms in the pfcoronin and pfk13 genes and the presence of Plasmodium falciparum parasites after treatment with artemisinin derivatives in Senegal. Int J Antimicrob Agents. 2020;56:106190.

21. Velavan TP, Nderu D, Agbenyega T, Ntoumi F, Kremsner PG. An alternative dogma on reduced artemisinin susceptibility: a new shadow from east to west. Proc Natl Acad Sci USA. 2019:116:12611-2.

22. Jambou R, Legrand E, Niang M, Khim N, Lim P, Volney B, et al. Resistance of Plasmodium falciparum field isolates to in-vitro artemether and point mutations of the SERCA-type PfATPase6. Lancet. 2005;366:1960-3.

23. Uhlemann AC, Cameron A, Eckstein-Ludwig U, Fischbarg J, Iserovich $P$, Zuniga FA, et al. A single amino acid residue can determine the sensitivity of SERCAs to artemisinins. Nat Struct Mol Biol. 2005;12:628-9.

24. Eckstein-Ludwig U, Webb RJ, Van Goethem ID, East JM, Lee AG, Kimura $M$, et al. Artemisinins target the SERCA of Plasmodium falciparum. Nature. 2003;424:957-61.

25. Krishna S, Woodrow CJ, Staines HM, Haynes RK, Mercereau-Puijalon OJTimm. Re-evaluation of how artemisinins work in light of emerging evidence of in vitro resistance. Trends Mol Med. 2006;12:200-5.

26. Toyoshima C, Inesi GJ. Structural basis of ion pumping by Ca2+-ATPase of the sarcoplasmic reticulum. Annu Rev Biochem. 2004;73:269-92.

27. Toyoshima CJ. How Ca2+-ATPase pumps ions across the sarcoplasmic reticulum membrane. Biochim Biophys Acta. 2009;1793:941-6.

28. Wuytack F, Raeymaekers L, Missiaen LJC. Molecular physiology of the SERCA and SPCA pumps. Cell Calcium. 2002;32:279-305.

29. Kimura M, Yamaguchi Y, Takada S, Tanabe KJ. Cloning of a Ca (2+)-ATPase gene of Plasmodium falciparum and comparison with vertebrate $\mathrm{Ca}$ (2+)-ATPases. J Cell Sci. 1993;104:1129-36.

30. Chilongola J, Ndaro A, Tarimo H, Shedrack T, Barthazary S, Kaaya R, et al. Occurrence of pfatpase6 single nucleotide polymorphisms associated with artemisinin resistance among field isolates of Plasmodium falciparum in North-Eastern Tanzania. Malar Res Treat. 2015;2015:279028.

31. Cui L, Wang Z, Jiang H, Parker D, Wang H, Su XZ, et al. Lack of association of the $5769 \mathrm{~N}$ mutation in Plasmodium falciparum SERCA (PfATP6) with resistance to artemisinins. Antimicrob Agents Chemother. 2012;56:2546-52.

32. Moher D, Liberati A, Tetzlaff J, Altman DG, Group P. Preferred reporting items for systematic reviews and meta-analyses: the PRISMA statement. PLOS Med. 2009;6:e1000097.

33. WHO. Artemisinin resistance and artemisinin-based combination therapy efficacy: status report. 2018. https://apps.who.int/iris/handle/10665/ 274362. 2019.

34. Abubakar UF, Adam R, Mukhtar MM, Muhammad A, Yahuza AA, Ibrahim SS. Identification of mutations in antimalarial resistance gene kelch13 from Plasmodium falciparum isolates in Kano. Nigeria Trop Med Infect Dis. 2020;5:85.

35. Ahouidi A, Oliveira R, Lobo L, Diedhiou C, Mboup S, Nogueira F. Prevalence of pfk13 and pfmdr1 polymorphisms in Bounkiling Southern Senegal. PLoS One. 2021;16:e0249357.

36. Balikagala B, Mita T, Ikeda M, Sakurai M, Yatsushiro S, Takahashi N, et al. Absence of in vivo selection for K13 mutations after artemether-lumefantrine treatment in Uganda. Malar J. 2017;16:23.

37. Conrad MD, Nsobya SL, Rosenthal PJ. The Diversity of the Plasmodium falciparum $\mathrm{K} 13$ propeller domain did not increase after implementation of artemisinin-based combination therapy in Uganda. Antimicrob Agents Chemother. 2019;63:e01234-e1319.

38. Djaman JA, Olefongo D, Ako AB, Roman J, Ngane VF, Basco LK, et al. Molecular epidemiology of malaria in Cameroon and Côte d'Ivoire XXXI. Kelch 13 propeller sequences in Plasmodium falciparum isolates before and after implementation of artemisinin-based combination therapy. Am J Trop Med Hyg. 2017:97:222-4.

39. Uwimana A, Legrand E, Stokes BH, Ndikumana JM, Warsame M, Umulisa $\mathrm{N}$, et al. Emergence and clonal expansion of in vitro artemisinin-resistant Plasmodium falciparum kelch13 R561H mutant parasites in Rwanda. Nat Med. 2020;26:1602-8 
40. Tornyigah B, Coppée R, Houze P, Kusi KA, Adu B, Quakyi I, et al. Effect of drug pressure on promoting the emergence of antimalarial-resistant parasites among pregnant women in Ghana. Antimicrob Agents Chemother. 2020;64:e02029-e2119.

41. Pacheco MA, Schneider KA, Cheng Q, Munde EO, Ndege C, Onyango C, et al. Changes in the frequencies of Plasmodium falciparum dhps and dhfr drug-resistant mutations in children from Western Kenya from 2005 to 2018: the rise of Pfdhps S436H. Malar J. 2020;19:378.

42. Ocan M, Bwanga F, Okeng A, Katabazi F, Kigozi E, Kyobe S, et al. Prevalence of K13-propeller gene polymorphisms among Plasmodium falciparum parasites isolated from adult symptomatic patients in northern Uganda. BMC Infect Dis. 2016;16:428.

43. Oboh MA, Ndiaye D, Antony HA, Badiane AS, Singh US, Ali NA, et al. Status of artemisinin resistance in malaria parasite Plasmodium falciparum from molecular analyses of the Kelch13 gene in Southwestern Nigeria. Biomed Res Int. 2018;2018:2305062.

44. Nzoumbou-Boko R, Panté-Wockama CG, Ngoagoni C, Petiot N, Legrand E, Vickos U, et al. Molecular assessment of kelch13 non-synonymous mutations in Plasmodium falciparum isolates from Central African Republic (2017-2019). Malar J. 2020;19:191.

45. Mayengue PI, Niama RF, Kouhounina Batsimba D, Malonga-Massanga A, Louzolo I, Loukabou Bongolo NC, et al. No polymorphisms in K13-propeller gene associated with artemisinin resistance in Plasmodium falciparum isolated from Brazzaville. Republic of Congo BMC Infect Dis. 2018;18:538.

46. Castaneda-Mogollon DR, Bayih AG, Abere A, Amarasekara R, Tesfa H, Pillai DR. Using amplicon deep sequencing to characterize clonal expansion of a kelch 13 r622i mutant in Gondar. Ethiopia Am J Trop Med Hyg. 2019;101:102

47. Chebore W, Zhou Z, Westercamp N, Otieno K, Shi YP, Sergent SB, et al. Prevalence of Pfmdr1, Pfk13 and Pfcrt polymorphisms during a therapeutic efficacy study in western Kenya. Am J Trop Med Hyg. 2018;99:85-6.

48. de Laurent ZR, Chebon LJ, Ingasia LA, Akala HM, Andagalu B, OcholaOyier LI, et al. Polymorphisms in the K13 gene in Plasmodium falciparum from different malaria transmission areas of Kenya. Am J Trop Med Hyg. 2018:98:1360-6.

49. Hemming-Schroeder E, Umukoro E, Lo E, Fung B, Tomás-Domingo P, Zhou G, et al. Impacts of antimalarial drugs on Plasmodium falciparum drug resistance markers, Western Kenya, 2003-2015. Am J Trop Med Hyg. 2018;98:692-9.

50. Ikeda M, Kaneko M, Tachibana SI, Balikagala B, Sakurai-Yatsushiro M, Yatsushiro S, et al. Artemisinin-resistant plasmodium falciparum with high survival rates, uganda, 2014-2016. Emerg Infect Dis. 2018;24:718-26.

51. Gaye A, Sy M, Ndiaye T, Siddle KJ, Park DJ, Deme AB, et al. Amplicon deep sequencing of kelch13 in Plasmodium falciparum isolates from Senegal. Malar J. 2020;19:134.

52. Guerra M, Neres R, Salgueiro P, Mendes C, Ndong-Mabale N, Berzosa P, et al. Plasmodium falciparum genetic diversity in continental Equatorial Guinea before and after introduction of artemisinin-based combination therapy. Antimicrob Agents Chemother. 2017;61:e02556-e2615.

53. Gupta H, Galatas B, Chidimatembue A, Huijben S, Cisteró P, Matambisso $G$, et al. Effect of mass dihydroartemisinin-piperaquine administration in southern Mozambique on the carriage of molecular markers of antimalarial resistance. PLoS One. 2020;15:e0240174.

54. Hussien M, Abdel Hamid MM, Elamin EA, Hassan AO, Elaagip AH, Salama $\mathrm{AHA}$, et al. Antimalarial drug resistance molecular makers of Plasmodium falciparum isolates from Sudan during 2015-2017. PLoS One. 2020;15:e0235401.

55. Kakolwa MA, Mahende MK, Ishengoma DS, Mandara Cl, Ngasala B, Kamugisha E, et al. Efficacy and safety of artemisinin-based combination therapy, and molecular markers for artemisinin and piperaquine resistance in Mainland Tanzania. Malar J. 2018;17:369.

56. Ishengoma DS, Mandara Cl, Francis F, Talundzic E, Lucchi NW, Ngasala B, et al. Efficacy and safety of artemether-lumefantrine for the treatment of uncomplicated malaria and prevalence of Pfk 13 and Pfmdr1 polymorphisms after a decade of using artemisinin-based combination therapy in mainland Tanzania. Malar J. 2019:18:88.

57. Kayiba NK, Yobi DM, Tshibangu-Kabamba E, Tuan VP, Yamaoka Y, Devleesschauwer B, et al. Spatial and molecular mapping of Pfkelch13 gene polymorphism in Africa in the era of emerging Plasmodium falciparum resistance to artemisinin: a systematic review. Lancet Infect Dis. 2021;21:e82-92.
58. Yobi DM, Kayiba NK, Mvumbi DM, Boreux R, Kabututu PZ, Situakibanza HNT, et al. Assessment of Plasmodium falciparum anti-malarial drug resistance markers in pfk13-propeller, pfcrt and pfmdr1 genes in isolates from treatment failure patients in Democratic Republic of Congo, 2018-2019. Malar J. 2021;20:144.

59. Talundzic E, Ndiaye YD, Deme AB, Olsen C, Patel DS, Biliya S, et al. Molecular epidemiology of Plasmodium falciparum kelch13 mutations in Senegal determined by using targeted amplicon deep sequencing. Antimicrob Agents Chemother. 2017;61:144

60. L'Episcopia M, Kelley J, Patel D, Schmedes S, Ravishankar S, Menegon M, et al. Targeted deep amplicon sequencing of kelch 13 and cytochrome $\mathrm{b}$ in Plasmodium falciparum isolates from an endemic African country using the Malaria Resistance Surveillance (MaRS) protocol. Parasit Vectors. 2020;13:137.

61. Boussaroque A, Fall B, Madamet M, Camara C, Benoit N, Fall M, et al. Emergence of Mutations in the K13 propeller gene of Plasmodium falciparum Isolates from Dakar, Senegal, in 2013-2014. Antimicrob Agents Chemother. 2016;60:624-7.

62. Torrentino-Madamet M, Fall B, Benoit N, Camara C, Amalvict R, Fall M, et al. Limited polymorphisms in $\mathrm{k} 13$ gene in Plasmodium falciparum isolates from Dakar, Senegal in 2012-2013. Malar J. 2014;13:472.

63. Bwire GM, Ngasala B, Mikomangwa WP, Kilonzi M, Kamuhabwa AAR. Detection of mutations associated with artemisinin resistance at k13-propeller gene and a near complete return of chloroquine susceptible falciparum malaria in Southeast of Tanzania. Sci Rep. 2020;10:3500.

64. Xu C, Wei Q, Yin K, Sun H, Li J, Xiao T, et al. Surveillance of antimalarial resistance Pfcrt, Pfmdr1, and Pfkelch13 polymorphisms in African Plasmodium falciparum imported to Shandong Province. China Sci Rep. 2018;8:12951.

65. Heuchert A, Abduselam N, Zeynudin A, Eshetu T, Loscher T, Wieser A, et al. Molecular markers of anti-malarial drug resistance in southwest Ethiopia over time: regional surveillance from 2006 to 2013. Malar J. 2015;14:208.

66. Koukouikila-Koussounda F, Jeyaraj S, Nguetse CN, Nkonganyi CN, Kokou KC, Etoka-Beka MK, et al. Molecular surveillance of Plasmodium falciparum drug resistance in the Republic of Congo: four and nine years after the introduction of artemisinin-based combination therapy. Malar J. 2017;16:155.

67. Kwansa-Bentum B, Ayi I, Suzuki T, Otchere J, Kumagai T, Anyan WK, et al. Plasmodium falciparum isolates from southern Ghana exhibit polymorphisms in the SERCA-type PfATPase6 though sensitive to artesunate in vitro. Malar J. 2011;10:187.

68. Li J, Chen J, Xie D, Eyi UM, Matesa RA, Ondo Obono MM, et al. Limited artemisinin resistance-associated polymorphisms in Plasmodium falciparum K13-propeller and PfATPase6 gene isolated from Bioko Island, Equatorial Guinea. Int J Parasitol Drugs Drug Resist. 2016;6:54-9.

69. Zakeri S, Hemati S, Pirahmadi S, Afsharpad M, Raeisi A, Djadid ND. Molecular assessment of atpase6 mutations associated with artemisinin resistance among unexposed and exposed Plasmodium falciparum clinical isolates to artemisinin-based combination therapy. Malar J. 2012;11:373.

70. Kone A, Sissoko S, Fofana B, Sangare CO, Dembele D, Haidara AS, et al. Different Plasmodium falciparum clearance times in two Malian villages following artesunate monotherapy. Int J Infect Dis. 2020;95:399-405.

71. Oyebola KM, Aina OO, Idowu ET, Olukosi YA, Ajibaye OS, Otubanjo OA, et al. A barcode of multilocus nuclear DNA identifies genetic relatedness in pre- and post-Artemether/Lumefantrine treated Plasmodium falciparum in Nigeria. BMC Infect Dis. 2018;18:392.

72. Li GQ, Guo XB, Fu LC, Jian HX, Wang XH. Clinical trials of artemisinin and its derivatives in the treatment of malaria in China. Trans R Soc Trop Med Hyg. 1994;88(Suppl 1):S5-6.

73. Tacoli C, Gai PP, Bayingana C, Sifft K, Geus D, Ndoli J, et al. Artemisinin resistance-associated K13 polymorphisms of Plasmodium falciparum in Southern Rwanda, 2010-2015. Am J Trop Med Hyg. 2016;95:1090-3.

74. Escobar C, Pateira S, Lobo E, Lobo L, Teodosio R, Dias F, et al. Polymorphisms in Plasmodium falciparum K13-propeller in Angola and Mozambique after the introduction of the ACTs. PLoS One. 2015;10:e0119215.

75. Ouattara A, Kone A, Adams M, Fofana B, Walling-Maiga A, Gil JP, et al. K13-propeller, MAL10 and MAL13 and polymorphisms in in vivo artemisinin susceptible Plasmodium falciparum parasites from bougoulahameau Mali. Am J Trop Med Hyg. 2014;91:97.

76. Tahar R, Ringwald P, Basco LK. Molecular epidemiology of malaria in Cameroon XXVIII. In vitro activity of dihydroartemisinin against clinical isolates 
of Plasmodium falciparum and sequence analysis of the $P$. falciparum ATPase 6 gene. Am J Trop Med Hyg. 2009;81:13-8.

77. Henrici RC, Sutherland CJ. Alternative pathway to reduced artemisinin susceptibility in Plasmodium falciparum. Proc Natl Acad Sci USA.

2018;115:12556-8.

\section{Publisher's Note}

Springer Nature remains neutral with regard to jurisdictional claims in published maps and institutional affiliations.

- fast, convenient online submission

- thorough peer review by experienced researchers in your field

- rapid publication on acceptance

- support for research data, including large and complex data types

- gold Open Access which fosters wider collaboration and increased citations

- maximum visibility for your research: over $100 \mathrm{M}$ website views per year

At BMC, research is always in progress.

Learn more biomedcentral.com/submissions 